Resumen por el autor, Ralph A. Kordenat, Universidad de Illinois.

Contaminación de los cadáveres por el Saccharomyces cerevisiae.

El crecimiento de hongos sobre los cadáveres es causa de considerable pérdida de material en los laboratorios anatómicos. El presente trabajo da a conocer la existencia de tal contaminación. Un estudio de los caracteres de los cultivos de dichos hongos, sus propiedades de coloración, morfología y experimentos sobre animales, demuestran que esta "]evadura" es una variedad no patógena y saprofítica del Saccharomyces cerevisiae. Un estudio de varios germicídas y antisépticos demostró que el crecimiento de estos hongos se impide embalsamando los cadáveres con la siguiente fórmula: Glicerina, $300 \mathrm{cc.;} \mathrm{formol,} 400$ cc.; alcohol, 1000 cc.; fenol, 90 gramos; agua, 400 cc. Primero se usó el bicloruro de mercurio (90 gramos), pero después se omitió su empleo porque forma un coágulo resistente y granular en los vasos sanguíneos, que impide la penetración completa del liquido embalsamador, y, además, por el coste de dicha substancia química. Su presencia en el cadáver no es necesaria para impedir el crecimiento del hongo. Como medida profiláctica paños mojados en la siguiente solución, con los que se envuelven los cuerpos, impiden el crecimiento de la levadura así como la desecación y endurecimiento rápidos de los músculos expuestos. La solución se compone de: Glicerina, 50 cc.; fenol, 2 gramos; alcohol, 50 cc.; agua (que se añadirá) $1000 \mathrm{cc}$.

Translation by José F. Nonidez

Cornell University Medical College, N. Y. 


\title{
CONTAMINATION OF CADAVERS BY SACCHAROMYCES CEREVISIAE
}

\author{
RALPH A. KORDENAT \\ Departments of Bacteriology and Anatomy, University of Illinois College of \\ Medicine, Chicago, Illinois \\ TWO FIGTRES
}

Recently the cadavers in the anatomical laboratories of the University of Illinois, College of Medicine, became covered by a moist, slimy, slightly elevated growth that has caused no small amount of trouble and annoyance. The growth is dirty gray in color, loosely adherent, and does not penetrate the deeper tissues. It has never been noticed upon the unbroken skin of the cadaver; when the skin is removed, however, the growth begins and spreads with great rapidity, making dissection of the specimen out of the question and causing great waste of material.

A quantity of this grayish substance was taken to the bacteriological laboratory for examination. Smears showed a large number of highly refractive, ovoid cells, measuring about $7_{\mu}$ in diameter. In addition to these, there were large numbers of bacteria, especially staphylococci.

It seemed plain that the slimy growth was largely made up of the above-mentioned ovoid cells, and cultures were therefore made in order to isolate and study them in detail.

After several attempts, pure cultures of the organism in question were obtained.

\section{CULTURAL CHARACTERISTICS}

Neutral plain agar. After twenty-four hours' incubation at $37^{\circ} \mathrm{C}$. small, round, bluish-gray colonies, about the size of a pinhead were seen. Their margins were smooth and regular. After an additional twenty-four hours' incubation at room temperature 
these colonies turned white in color, but did not increase in size or number.

Five per cent dextrose agar. Twenty-four-hour culures showed a growth similar to that on plain agar. After another twentyfour hours at room temperature they were much larger and creamy white in color, becoming confluent in most cases so as to cover the entire surface of the media. The characteristic odor of 'yeast' was noticed.

Plain broth. The growth in plain broth was not profuse. There was a slight flocculent sediment at the end of twenty-four hours. The broth was slightly turbid.

Five per cent dextrose broth. The growth was similar to that in plain broth, but more pronounced; a heavy sediment and the characteristic odor of yeast.

Litmus milk. A marked acid production at the end of fortyeight hours with coagulation; the curd in most cases being completely digested, leaving a whitish turbid whey.

Gelatin stabs. Gelatin-stab cultures showed only a slight growth upon the surface, resembling that on plain agar. No liquefaction.

The organism ferments glucose with the formation of carbon dioxide and alcohol.

\section{STAINING PROPERTIES}

The organism stains fairly well with the ordinary dyes and exceptionally well by the Gram method, being strongly Grampositive (figs. 1 and 2). When stained by Wright's stain, a welldefined blue cell membrane is seen with pale blue mitochondria and numerous vacuoles within.

\section{MORPHOLOGY}

The organisms average about $7 \mu$ in diameter and are round to ovoid in form. In a hanging-drop preparation of a forty-eighthour culture, a highly refractive, non-motile, double-contoured cell is seen in an active state of budding. The budding generally takes place from the long end of the ovoid cells. The younger 
cells are small and more rounded in form, while the older cells, from which the budding takes place, are more elongated. There is no tendency to form mycelia.

A pure known culture of Saceharomyces cerevisiae was compared with the organism taken from the cadaver, and it was found that in every way the two resembled each other in morphology, staining properties, and in general cultural characteristics.

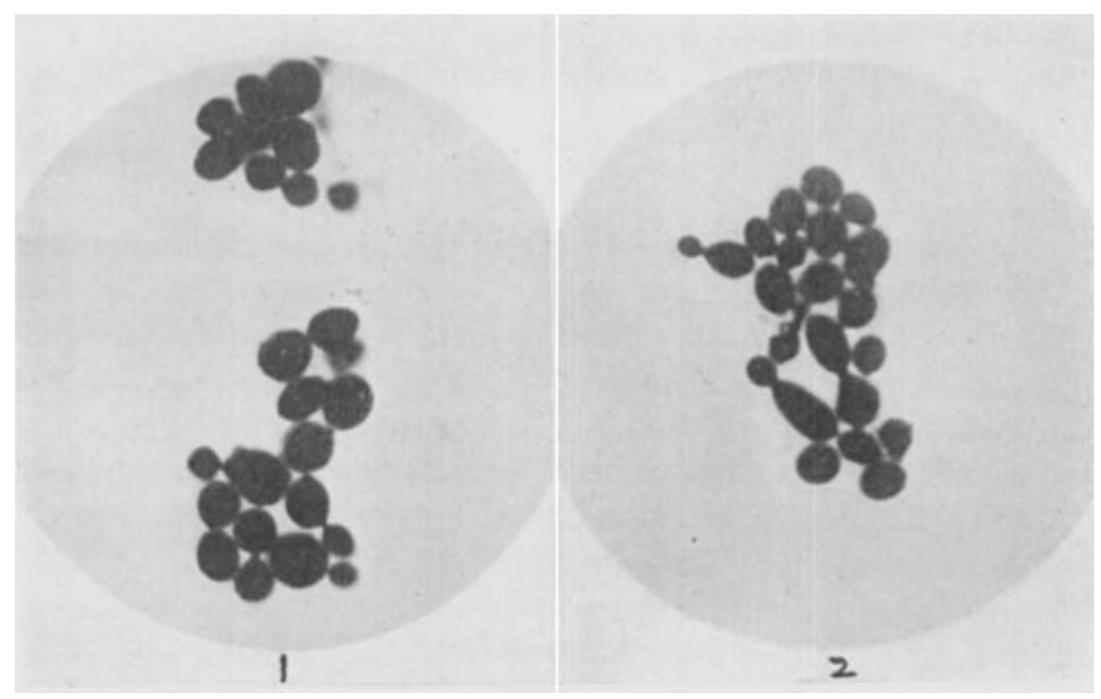

Fig. 1 Strain 'A.' Saccharomyces cerevisiae from cadaver. Gram's stain $(\times 1200)$.

Fig. 2 Strain 'B.' Known pure culture of Saccharomyces cerevisiae. Gram's stain $(\times 1200)$.

\section{ANIMAL EXPERIMENTS}

White mice, after being inoculated with rather large doses of a normal salt suspension of the organism, showed no ill effects.

An effort was made to reproduce the growth upon animals. Two dead rabbits, with the skin and viscera removed, were immersed in the embalming fluid used for the preparation of the bodies in the anatomical laboratories. This embalming fluid consists of- 


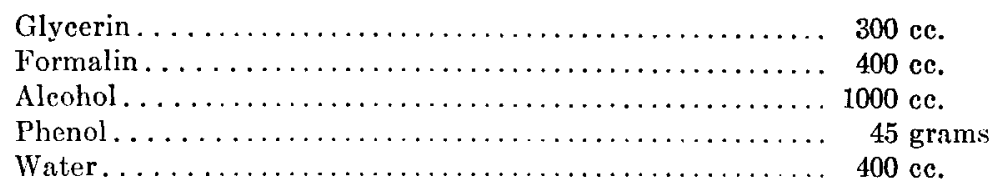

$\Lambda$ fter a period of one week they were removed and a pure culture of the cadaver organism planted upon one and a pure known culture of Saccharomyces cerevisiae planted upon the other. At the end of three days the entire bodies of the two rabbits were similarly covered with a slimy, grayish film. Two days later this growth became a dirty, creamy white and resembled that found upon the cadavers. Thus, it is further evident that the two organisms are alike.

\section{THERMAL DEATH POINT}

A series of small test-tubes, each containing $2 \mathrm{cc}$. of a suspension of the cadaver culture (strain ' $A$ ') and a known strain of Saccharomyces cerevisiae (strain ' $B$ ') were used. At the different degrees of temperature indicated in the table, tubes of each of the two organisms were placed in a water-bath for a period of ten minutes, allowing one minute for the temperature of the tubes to reach that of the water-bath. The tubes were then removed and 5 per cent dextrose-agar slants inoculated and incubated. The results are given in the table. Both organisms were killed at $58^{\circ} \mathrm{C}$. for ten minutes, but not at $56^{\circ} \mathrm{C}$. for ten minutes.

Because of the apparent identity of the cultural characteristics and staining properties, as well as the results of the animal experiments with the organisms, it is further evident that the contamination of the cadavers is a strain of Saccharomyces cerevisiae.

I have been able to find nothing in the literature concerning the contamination of cadavers by Saccharomyces cerevisiae. In a personal communication from Dr. Irving Hardesty, of Tulane University, he states that he has had a similar experience with 'molds,' that the mold thrives on formalin-hardened bodies, that alcohol favors its growth, and that carbolic acid will not check it unless the bodies are completely immersed in the carbolic solution. 
In order to find some disinfectant for this organism that might be effective in embalming fluids, the following experiments were performed:

The carbolic coefficients for potassium chromate, formalin, and mercuric bichloride were determined according to the method advocated by the U. S. P. H. S. (Hygienic Laboratory Bulletin no. 82) and further described by M. J. Rosenau in his test on "Preventive Medicine and Hygiene." Instead, however, of finding the coefficient with the use of a twenty-four hour culture of typhoid bacillus, forty-eight hour cultures of the two strains of

TABLE 1

Thermal death point

\begin{tabular}{c|c|c}
\hline $\begin{array}{c}\text { TEMPERATURE (10-MINUTE } \\
\text { EXPOBURE) }\end{array}$ & BTRAIN 'A' GROWTH & BTRAIN 'B' GROWTB \\
\cline { 1 - 2 }${ }^{\circ} \mathrm{C}$. & Positive & Positive \\
48 & Positive & Positive \\
50 & Positive & Positive \\
52 & Positive & Positive \\
56 & Negative & Negative \\
58 & Negative & Negative \\
62 & Negative & Negative \\
64 & Negative & Negative \\
68 & Negative & Negative \\
70 & Negative & Negative \\
72 & Negative & Negative \\
74 & Negative & Negative \\
78 & &
\end{tabular}

Saccharomyces cerevisiae were used, because the yeast is in its most active state of budding at that time. It was found, by determining the carbolic coefficient, that phenol is the most efficient disinfectant for these yeasts. The action of mercuric bichloride toward these organisms is too inconstant for one to reach any definite conclusion as to its use. Formalin and potassium chromate have too low a coefficient to be of any value.

The prevention of this growth was now attempted by altering the composition of the embalming fluid previously used. A rabbit was embalmed with the following fluid: 


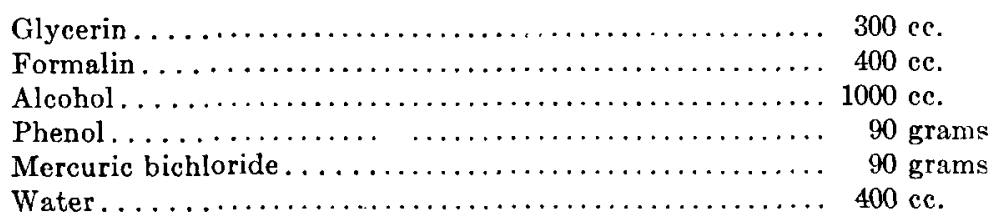

It will be seen that this solution differs from the one previously mentioned in that the phenol is doubled and mercuric bichloride is added. The rabbit was immersed in the same solution for three days, seeded with cultures of both yeasts, and then covered with moist towels. At the end of four days there was no growth. It was considered inadvisable to include mercuric bichloride in the embalming fluid not only because of the extra expense, but because there is a granular coagulation of the blood in the small vessels. This firm, granular coagulum completely obstructs the smaller vessels, thus preventing the thorough penetration of the solution. Other rabbits, embalmed with the same fluid minus the mercuric bichloride, were seeded with both strains of the yeast and incubated for four days. These also showed no growth.

An examination was made of the dust taken from the floor, walls, and tables of the anatomical laboratory. Some of this dust was taken up by means of a sterile cotton swab and 5 per cent dextrose broth and agar inoculated and then incubated for twenty-four hours at room temperature. Many of the samples revealed Saccharomyces cerevisiae.

As a prophylactic measure, cloth was soaked with the following solution:

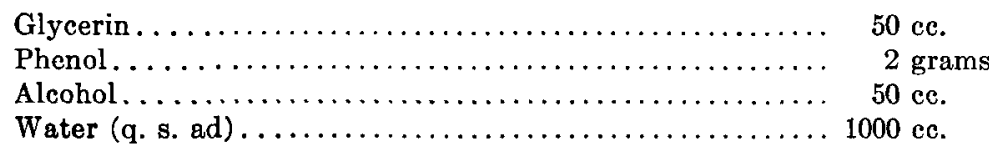

and was draped over one-half of the bodies in the laboratory (group A) at the end of each dissection for a period of four months. The other half of the cadavers (group B) served as a control. During these four months none of the bodies of group A was affected, while six of the bodies of group B became covered with the growth, 
By applying the above solution upon the embalmed bodies, the specimens are not only protected from the yeast but the glycerin keeps the exposed muscles more soft and pliable.

\section{CONCLUSIONS}

Because of the apparent identity of the cultural characteristies, morphology, staining properties, and of the animal experiments mentioned, it is concluded that the organism in question is a saprophytic strain of Saccharomyces cerevisiae.

The growth of Saccharomyces cerevisiae upon anatomical specimens renders them useless, thereby causing great waste of material.

Phenol is the most efficient disinfectant for this particular strain of yeast.

The contamination can be prevented by using the embalming fluids and the prophylactic measures mentioned.

The use of mercuric bichloride in embalming fluids is not practical; first, because it forms a firm granular coagulum of blood in the vessels, thus preventing the complete penetration of the fluid, and, second, because of the expense of the chemical. The prophylactic measures indicated not only protect the cadavers from the Saccharomyces cerevisiae, but prevent rapid drying and hardening of the exposed muscles. 